\title{
KEPEMIMPINAN IDEAL DALAM LEMBAGA PENDIDIKAN
}

\author{
ANDRIANI TUNNISA ${ }^{1}$, NURUL INAYAH MAKMUR ${ }^{2}$, ZAKIAH HASAN ${ }^{3}$ \\ 123Pascasarjana Universitas Islam Negeri Alauddin Makassar, Indonesia \\ Email: ${ }^{1}$ andrianibtg5@gmail.com, ${ }^{2}$ ninayaahmkr@gmail.com, ${ }^{3}$ zakiahhr@gmail.com
}

\begin{abstract}
Ideal Leadership in Educational Institutions
Leadership is a major factor in the goals of an institution or organization. However, in the goal effort, you must pay attention to the behavior of subordinates where this behavior is considered by the leader to make decisions. The quality of leadership determines the direction of success of the institution or organization. Leadership has a strategic role in the management framework. The role of a leader is basically a function of leadership. While the leadership function itself is one of the roles of managers in the framework of influencing subordinates or followers to willingly provide dedication in achieving organizational goals, in accordance with the abilities of subordinates to the fullest.
\end{abstract}

Keywords: Leadership Theory, Ideal Leadership, Educational Institutions

\begin{abstract}
Abstrak: Kepemimpinan Ideal dalam Lembaga Pendidikan
Kepemimpinan merupakan faktor utama dalam pencapaian tujuan sebuah lembaga atau organisasi. Namun dalam usaha pencapaian tujuan harus tetap memperhatikan perilaku para bawahan dimana perilaku tersebut sebagai pertimbangan oleh pemimpin untuk mengambil keputusan. Kualitas kepemimpinan menentukan arah keberhasilan lembaga atau organisasinya. Kepemimpinan memiliki peranan strategis dalam kerangka manajemen. Sebab peranan seorang pemimpin pada dasarnya merupakan serangkaian fungsi kepemimpinan. Sedangkan fungsi kepemimpinan itu sendiri merupakan salah satu di antara peranan manajer dalam kerangka untuk mempengaruhi bawahan atau pengikutnya agar dengan penuh kemauan memberikan pengabdian dalam mencapai tujuan organisasi, sesuai dengan kemampuan bawahan secara maksimal.
\end{abstract}

Kata Kunci: Teori Kepemimpinan, Kepemimpinan Ideal, Lembaga Pendidikan

\section{PENDAHULUAN}

Kepemimpinan adalah salah satu roda penggerak sebuah lembaga atau organisasi. Kualitas kepemimpinan menentukan arah keberhasilan lembaga atau organisasinya. Suatu pandangan yang bersifat lebih umum menyatakan bahwa manajemen adalah proses mengintegrasikan sumber-sumber yang tidak berhubungan menjadi sistem total untuk menyelesaikan suatu tujuan (Pidarta, 
1998). Artinya, manajemen merupakan suatu kepedulian untuk mengaplikasikan tujuan atau sasaran organisasi.

Kepemimpinan memiliki peranan strategis dalam kerangka manajemen. Sebab peranan seorang pemimpin pada dasarnya merupakan serangkaian fungsi kepemimpinan. Sedangkan fungsi kepemimpinan itu sendiri merupakan salah satu di antara peranan manajer dalam kerangka untuk mempengaruhi bawahan atau pengikutnya agar dengan penuh kemauan memberikan pengabdian dalam mencapai tujuan organisasi, sesuai dengan kemampuan bawahan secara maksimal. Faktor penentu keberhasilan seorang pemimpin di antaranya adalah "teknik kepemimpinan", yaitu bagaimana seorang pemimpin mampu menciptakan situasi sehingga menyebabkan orang yang dipimpinnya timbul kesadarannya untuk melaksanakan apa yang dikehendaki oleh seorang pemimpin. Dengan kata lain, efektif atau tidaknya seorang pemimpin tergantung bagaimana kemampuannya dalam mengelola dan menerapkan pola kepemimpinannya sesuai dengan situasi dan kondisi dalam organisasi tersebut (Samsu, 2014). Pemimpin harus terus menerus mengupayakan kedisiplinan agar dapat dipertahankan dan dimajukan melalui kesadaran anggota organisasi akan tanggung jawabnya dalam menjalankan tugasnya (Astuti \& Danial, 2019).

Pemimpin saat ini dan akan dituntut untuk bersikap fleksibel, mampu beradaptasi dengan lingkungan yang bersifat dinamis serta mampu menindaklanjuti segala bentuk perubahan dan secara aktif membuat variasi program perubahan yang dibutuhkan. Setiap pemimpin memiliki gaya kepemimpinan yang berbeda antara satu dan lainnya. Cara pandang mengenai isuisu tertentu menjadi kapasitas kepemimpinan individu. Tidak bisa dipungkiri bahwa menjadi seorang pemimpin harus bertanggung jawab dan memiliki peran yang berat dan berpengaruh. Akan tetapi, setiap hal dapat diatasi jika ia menggunakan taktik dan strategi yang sesuai dengan keadaannya (Badu \& Djafri, 2017).

\section{PEMBAHASAN}

\section{Konsep Kepemimpinan}

Ada beberapa konsep yang mendefinisikan kepemimpinan yang telah dikemukakan oleh para ahli manajemen secara representatif, di antaranya C. Turney (1992, h. 47) mendefinisikan kepemimpinan sebagai group proses yang dilakukan oleh seseorang dalam me-manage dan menginspirasikan sejumlah pekerjaan untuk mencapai organisasi melalui aplikasi teknik-teknik manajemen. Lipham (1994, h. 182) mendefinisikan kepemimpinan sebagai perilaku seseorang yang menginisiatifkan suatu struktur baru dalam berinteraksi pada suatu sistem sosial, baik mengenai tujuan, sasaran, konfigurasi, prosedur-prosedur, input, 
proses, dan output pada sistem sosial tersebut. Steven (1985, h. 284) mendefinisikan usaha-usahanya ke arah pencapaian beberapa tujuan khusus.6 Dari beberapa definisi mengenai kepemimpinan di atas, maka penulis dapat menyimpulkan bahwa kepemimpinan merupakan suatu proses mempengaruhi yang dilakukan oleh seseorang dalam mengelola anggota kelompoknya untuk mencapai tujuan organisasi. Proses mempengaruhi ini tentunya bukan dengan jalan paksaan, tetapi bagaimana seorang pemimpin itu mampu berinteraksi dan menginspirasikan tugas kepada bawahannya dengan menerapkan teknik-teknik tertentu sesuai dengan situasi dan kondisi tertentu sehingga apa yang dituju dapat tercapai dengan sukses.

\section{Pentingnya Kepemimpinan dalam Sebuah Organisasi}

Manajemen yang baik oleh manajer yang berpengalaman dapat menyukseskan sebuah bisnis. Namun, keterampilan manajemen dasar tidak cukup untuk mencapai kesuksesan di dunia yang penuh dengan persaingan ini. Dibutuhkan keterampilan kepemimpinan (leadership skill) yang baik dan efektif untuk menciptakan, mendorong dan mempromosikan budaya yang kuat dalam perusahaan sampai meraih keberhasilan. Manajer biasanya dipahami sebagai pemimpin yang pada kenyataannya tidak semua manajer bisa menjadi pemimpin, meskipun seorang pemimpin merupakan manajer. Oleh karena itu, keterampilan kepemimpinan sangat penting untuk meningkatkan efisiensi dan mencapai tujuan organisasi.

Ada 3 sebab mengapa seseorang menjadi seorang pemimpin, antara lain yaitu: a) melalui berbagai persiapan dan pendidikan serta didorong oleh kemauan sendiri; b) memiliki bakat kepemimpinan sejak ia lahir yang kemudian dikembangkan melalui pendidikan dan pengalaman dan sesuai tuntutan lingkungan sekitar; dan 3) untuk persyaratan kepemimpinan yang dikaitkan dengan kekuasaan, kewibawaan, dan kemampuan. Pentingnya sebuah kepemimpinan yang efektif dapat dilihat melalui:

1. Produktivitas sebuah kemampuan dan kemauan dapat menghasilkan prestasi kerja yang efektif dan berdaya guna dengan memanfaatkan sumber daya manusia dan nonmanusia. Dalam kasus ini, seorang atasan berperan untuk memaksimalkan produktivitas pegawai melalui peningkatan kemauan untuk bekerja keras dan berkontribusi secara tepat guna.

2. Kepuasan kerja Memberikan lingkungan kerja yang baik dapat menambah kepuasan kerja pegawai yang bergantung pada perilaku pemimpin terhadap pegawainya. Dengan demikian, atasan harus memastikan bahwa ia bersikap sesuai dengan apa yang bisa diterima oleh bawahannya. 
3. Kerja sama kelompok Seorang atasan harus memastikan bahwa bawahannya mengerjakan tugas masing-masing dengan sebaik-baiknya dan saling percaya satu sama lain untuk memajukan organisasi mereka. Pemimpin memotivasi mereka dalam mencapai tujuan organisasi.

4. Kegiatan yang terorganisir Seorang pemimpin memastikan segala aktivitas organisasi didelegasikan secara adil dan merata pada pegawainya untuk menghindari bentrokan di lingkungan organisasi.

5. Semangat karyawan Semangat kerja yang tinggi dari seorang pegawai dapat membantu terwujudnya kepemimpinan yang efektif. Pemimpin yang bijaksana mampu memberikan hak kepada tiap kelompok dalam hal pemikiran dan perilaku, agar dapat terjalin interaksi yang lebih baik. Lebih lanjut, hubungan yang baik yang difasilitasi antara anggota kelompok dengan menjaga disiplin dan pengawasan pada karyawan.

6. Koordinasi Mengintegrasikan tujuan pribadi dan tujuan kelompok yang mengikat persamaan dari dua kepentingan. Pemimpin menyimpan informasi yang dibutuhkan kelompok, untuk membuat suatu keputusan umum dalam rangka mengkoordinasi upaya secara keseluruhan (Badu \& Djafri, 2017; h. 49-51).

\section{Faktor-Faktor Kepemimpinan}

Seseorang yang menduduki profesi pemimpin, khususnya pemimpin pendidikan, dalam menjalankan tugas kepemimpinannya dipengaruhi oleh faktorfaktor yang mewarnai pola kepemimpinan sebagai berikut (Samsu, 2014; h. 5859):

\section{Faktor-Faktor Legal}

Seseorang yang menduduki jabatan pemimpin pendidikan akan berhadapan dengan peraturan-peraturan formal dari instansi struktural yang berada di atasnya. Di Indonesia, falsafah Pancasila, UUD 1945, Keputusan Presiden, Keputusan Menteri, dan undang-undang lainnya akan mempengaruhi pola kepemimpinan pendidikan. Demikian pula dalam kaitannya dengan standar yang berkaitan dengan pengangkatannya sebagai pemimpin pendidikan. Misalnya yang berhubungan dengan sertifikasi, pola penyeleleksian, kualifikasi profesional dan tuntutan lainnya. Hal ini akan berpengaruh dalam kepemimpinan pendidikan seseorang.

\section{Kondisi Sosial Ekonomi dan Konsep-Konsep Pendidikan}

Faktor ini terdiri atas dua macam, yaitu: 1) Kondisi sosial ekonomi yang memungkinkan tersedianya sumber-sumber dan fasilitas pendidikan. Bantuan individu maupun masyarakat terhadap pendidikan dalam hal fasilitas akan membantu juga memperlancar jalannya pendidikan. Faktor sosial ekonomi 
pemimpin pendidikan juga akan mewarnai pola kepemimpinannya. 2) Konsep tujuan pendidikan para pemimpin masyarakat dan para warga pada umumnya akan berpengaruh terhadap pola kepemimpinan. Termasuk pemahaman pemimpin itu sendiri terhadap tujuan pendidikan akan mewarnai tindakan kepemimpinannya.

\section{Hakekat dan Ciri Lembaga Pendidikan}

Faktor ini berkaitan dengan ciri dan atau hakikat para staf, peserta didik dan jenis lembaga pendidikan, yang tentunya akan mempengaruhi kepemimpinan pendidikan. Sistem administrasi, kurikulum yang digunakan dan pendekatan yang digunakan dalam sistem pendidikan akan berpengaruh juga terhadap sistem kepemimpinan pendidikan.

\section{Kepribadian Pemimpin Pendidikan dan Latihan-Latihan}

Tidak dapat diingkari bahwa individu itu sendiri membawa sesuatu dalam jabatannya. Energi, loyalitas, pandangan hidup dan atribut-atribut profesional yang melekat padanya akan berpengaruh terhadap sistem kepemimpinan. Di samping hal di atas, pendidikan tambahan dan latihan-latihan yang memperkaya jabatan pimpinan akan mempengaruhi sistem kepemimpinannya.

\section{Perubahan-Perubahan yang Terjadi dalam Teori Pendidikan}

Tugas kepemimpinan pendidikan dipengaruhi oleh berbagai perubahan teori dan metode aktivitas belajar. Konsep-konsep pertumbuhan dan perkembangan anak membawa implikasi terhadap prosedur dan sistem pembelajaran. Hal ini akan berbeda dengan sepuluh tahun yang lalu atau lebih. Perubahan dan perkembangan kurikulum juga menghendaki persiapan kepemimpinan dan ketrampilan kepemimpinan yang baru. Yang jelas, perubahan dalam teori-teori pendidikan akan mengubah juga strategi pengelolaan dan kepemimpinan di lembaga pendidikan.

\section{Kepribadian dan Training Pemimpin Pendidikan}

Suatu kenyataan bahwa individu itu sendiri membawa sesuatu dalam pekerjaan. Tenaga, loyalitas, dan lain-lain atribut personal maupun profesional akan merupakan faktor signifikan yang berpengaruh terhadap jenis kepemimpinan. Oleh sebab itu suatu kewajiban moral dan profesional di Indonesia untuk menuntut adanya kualifikasi profesional dan personal untuk para pemimpin. Organisasi turut juga mempengaruhi kepemimpinan pemimpin. Kelompok-kelompok semacam itu membantu pemimpin menemukan pengetahuan, sehingga ia menjadi pribadi yang profesional. Di samping itu faktorfaktor yang memengaruhi perilaku seorang pemimpin seperti dijelaskan oleh Purwanto (2005, h. 59-61), yaitu: a) Keahlian dan pengetahuan yang dimiliki; b) Jenis pekerjaan atau lembaga; c) Sifat-sifat kepribadian pemimpin; d) Sifat-sifat 
kepribadian pengikut atau kelompok yang dipimpin; dan e) Sanksi-sanksi yang ada di tangan pemimpin.

\section{Gaya Kepemimpinan}

Gaya (style) merupakan suatu sifat, karakter atau kecenderungan seorang pemimpin dalam memimpin atau menggunakan kekuasaan dan kebijakan dalam suatu organisasi. Gaya seorang pemimpin dalam memimpin pada umumnya berbeda satu dengan yang lainnya tergantung kepada sifat, karakter dan kecenderungan atau situasi yang dihadapi seorang pemimpin dalam memimpin. Pemimpin adalah seseorang yang dipilih atau menjadi pemimpin serta memberikan pengaruh lantaran karena dibekali oleh sejumlah kemampuan. Sedangkan kepemimpinan merupakan sebuah pendekatan dalam proses memimpin berdasarkan kepada prinsip manajemen dengan mengedepankan kepentingan organisasi, prestasi kerja, bawahan dan kepemimpinan itu sendiri. Adapun yang dimaksud dengan prinsip manajemen di sini ialah planning (perencanaan), organizing (pengorganisasian), actuating (menggerakkan) dan controlling (pengawasan).

Terkait dengan kepemimpinan ini, dalam pandangan Islam setidaknya tugas dan peran kepemimpinan harus sejalan dengan tujuan penciptaan manusia itu sendiri. Dengan demikian, kepemimpinan hendaknya membawa manusia tersebut kepada tujuan penciptaan manusia agar kepemimpinan dapat membawa kepada keselamatan; bukan saja keselamatan organisasi, pemimpin tetapi juga bawahan yang dipimpinnya. Terdapat setidaknya enam tugas kepemimpinan tersebut yang terkait dengan tujuan penciptaan manusia, yaitu: a) Manusia diciptakan bukan secara main-main melainkan untuk mengemban amanah/tugas keagamaan, yaitu untuk mengabdi/ beribadah kepada Allah seperti dinyatakan dalam al-Qur'an (QS al-Mu'minuun, ayat 115); b) Manusia diciptakan untuk menjadi khalifah/wakil Allah/pengelola di muka bumi seperti dinyatakan dalam al-Qur'an (QS al-Ahzab, ayat 72 dan (QS al-Dzaariyaat, ayat 56); c) Manusia dibedakan derajatnya oleh Allah satu dengan yang lainnya untuk diuji oleh Allah atau derajat yang dimiliki tersebut seperti dinyatakan dalam al-Qur'an (QS al-Baqarah, ayat 30 dan QS alAn'am, ayat 165); d) Manusia diciptakan untuk misi amar ma'ruf nahi munkar, yaitu perintah untuk melakukan kebaikan dan mencegah kemungkaran) seperti dinyatakan dalam al-Qur'an (QS Ali Imran, ayat 110); e) Manusia diciptakan dan diperhatikan oleh Allah SWT seperti dinyatakan dalam al-Qur'an (QS al-Rahman, ayat 31); f) Manusia diciptakan oleh Allah untuk dimintai pertanggung jawabannya atas perbuatan yang mereka lakukan seperti dinyatakan dalam al-Qur'an (QS alQiyamah, ayat 36). 
Karakteristik kepribadian seorang pemimpin harus memiliki beberapa keistimewaan, diantaranya: adaptable (mudah menyesuaikan diri), assertive (lugas), charismatic (berwibawa dan berkharisma), creative (banyak ide), decisive (tegas mengambil keputusan), dominant (menonjol diantara rekan-rekannya), energetic (bertenaga dan berstamina tinggi), extraverted (berkepribadian terbuka), friendly (ramah terhadap siapa saja), honest (jujur), intelligent (cerdas), masculine (jantan), self-confident (percaya diri) dan wise (bijaksana). Sedangkan ciri-ciri fisik seorang pemimpin yang ideal di antaranya: athletic (atletis), attractive (menarik) dan tall (tinggi). Keberhasilan kepemimpinan ternyata bukan hanya dipengaruhi oleh sifat-sifat yang telah diwariskan sejak lahir saja, namun dipengaruhi oleh fungsi-fungsi dari berbagai faktor yaitu bakat, tempat dan waktu yang tepat (Haryono, 2015).

\section{Jenis-Jenis Gaya Kepemimpinan}

\section{Gaya Kepemimpinan Otokratis}

Karakteristik gaya kepemimpinan autokratik menunjukkan bahwa pemimpin autokrasi cenderung untuk memimpin dan menggunakan kekuasaan dengan cara paksa. Pada kepemimpinan autokrasi pemimpin membuat satu keputusan dan rakyat mesti mematuhi arahan tersebut. Ini adalah menyerupai struktur organisasi dan mekanistik dimana satu hirarki kekuasaan dan pembuatan keputusan adalah terpusat.

Hasan \& Mohd (2003, h. 61) mengemukakan bahwa istilah pemimpin autokratik juga dikenali sebagai pemimpin kuku besi. Pemimpin seperti ini sangat mementingkan status atau kedudukannya sebagai orang yang berkuasa. Bahkan satu segi, kepemimpinan autokratik sangat bertentangan dengan prinsip kebebasan individu, karena itu kebanyakan orang menilai gaya kepemimpinan autokratik secara negatif. Gaya ini lazimnya tidak disukai dan dianggap membahayakan organisasi yang dipimpin. Tetapi, dalam situasi tertentu gaya seperti ini ada kalanya sangat baik dan berkesan. Ia sangat sesuai digunakan apabila bawahan terdiri dari mereka yang tidak mempunyai banyak pengalaman dalam tugas-tugas yang mereka jalankan. Tetapi, seorang Pemimpin autokratik dibutuhkan bagi staf baru, dalam situasi kritis dan tidak ada waktu untuk menentukan keputusan kelompok. Pemimpin autokratis bekerja dengan sangat baik pada saat krisis dan dalam situasi genting (musibah) mereka telah memiliki reputasi untuk mampu menyelesaikan tugas yang sulit.

\section{Gaya Kepemimpinan Kharismatik}

Pemimpin kharismatik menurut Anderson dalam Ayub Ranoh sebenarnya hanya "kharismatik" di negaranya sendiri, dan tidak berarti bagi bangsa dengan 
konteks kultural dan religius yang berbeda (Ranoh, 2006). Menurut Wibawa \& Riyanto (2008, h. 60), seseorang pemimpin yang kharismatik ialah pemimpin yang dikagumi oleh banyak pengikut meskipun mereka tidak dapat menjelaskan secara kongkret mengapa ia mengaguminya.

Gaya kepemimpinan ini merupakan suatu gaya kepemimpinan yang mempunyai daya tarik yang amat besar terhadap para pengikutnya, seakan-akan dalam diri pemimpin itu ada sesuatu kekuatan yang sangat luar biasa. Kelemahannya adalah para bawahan tidak ada yang dapat mengusulkan pendapat, saran, dan pemikirannya.

\section{Gaya Kepemimpinan Demokratis}

Menurut Louis E. Boone dan David L. Kurtz gaya kepemimpinan demokratis melibatkan staf/bawahan dalam proses pengambilan keputusan. Gaya kepemimpinan ini berpusat pada kontribusi staf/bawahan. Pemimpin yang demokratis akan mendelegasikan pekerjaan, meminta saran dari karyawan dan mendorong partisipasi (Samsu, 2014).

Dalam gaya atau tipe kepemimpinan ini, bawahan atau staf berpartisipasi penuh dalam mencapai tujuan organisasi tanpa ada rasa paksaan. Di samping itu, juga turut mengembangkan pemikiran-pemikiran dalam menentukan atau memutuskan metode-metode yang terbaik dalam melaksanakan pekerjaan dan selalu mendengarkan pendapat bawahan dalam memutuskan suatu kebijakan. Dengan konsep kepemimpinan yang demokratis ini, pimpinan bertanggung jawab dalam mengembangkan kemampuan seluruh anggota, membangun hubungan kerja vertikal dan horizontal yang saling mendukung dan menciptakan iklim organisasi yang bergairah, sehingga kreativitas anggota dapat dipacu sedemikian rupa, dan pada gilirannya, akan menjamin berlangsungnya inovasi yang terus menerus. Sementara dalam hubungan ke luar, pimpinan bertanggung jawab dalam membina dan memelihara hubungan dengan organisasi lainnya, serta lingkungan masyarakat di sekitarnya.

\section{Gaya Kepemimpinan Partisipatif}

Hasanuddin Rahman Daeng Naja menyatakan gaya kepemimpinan partisipatif menganggap bawahan sebagai sumber manusia yang mampu berkontribusi terhadap efektivitas realisasi rencana yang telah disusun. Adapun anggapan tersebut membuat para bawahan merasa dihargai semangat dan prestasi kerja mereka dapat meningkat. Meskipun demikian, penerapan kepemimpinan partisipatif akan membawa risiko berupa lebih lamanya waktu yang diperlukan (Naja, 2004). 


\section{Gaya Kepemimpinan Transformasional}

Berbeda dengan gaya kepemimpinan demokratis, gaya kepemimpinan transformasional memfokuskan pada pemimpin yang memiliki sumbangan (impact) lain terhadap organisasi mereka. Menurut Bernad Bass, konsep kepemimpinan transformasional ini, memiliki dua jenis tingkah laku kepemimpinan, yaitu transaksional dan transformasional. Pemimpin transaksional; menentukan apa yang diinginkan oleh staf/bawahan untuk dilakukan untuk mencapai tujuan organisasi, hal demikian menyebabkan staf/bawahan percaya diri dalam mencapai tujuan dengan usaha dan reward. Berbeda dengan pemimpin transformasional; memotivasi staf/bawahan untuk bekerja lebih daripada yang diharapkan (Samsu, 2014).

\section{Gaya Kepemimpinan Situasional}

Kepemimpinan situasional menunjukkan kepada dua tingkah laku kunci, yaitu tingkah laku tugas dan tingkah laku hubungan. Selain dari itu, ada lagi gaya kepemimpinan yang disebut dengan gaya kepemimpinan kontingensi. Menurut Lunenburg dan Ornstein gaya kepemimpinan kontingensi menyatakan bahwa kepemimpinan yang baik adalah ditentukan oleh hubungan pemimpin dengan staf/bawahan dan struktur tugas serta kekuatan posisi tugas. Gaya kepemimpinan situasional adalah model gaya kepemimpinan yang memfokuskan pada pengikut. Gaya kepemimpinan situasional diterapkan dengan mengukur tingkat kesiapan dan kematangan dari para karyawan untuk menjalankan tugas yang diberikan oleh pimpinan. Dalam gaya kepemimpinan situasional, perilaku pemimpin berkaitan dengan tugas kepemimpinannya dan hubungan atasan dengan bawahan (Samsu, 2014).

Pendekatan kesifatan dan perilaku belum sepenuhnya dapat menjelaskan kepemimpinan. Di samping itu, sebagian besar penelitian masa kini menyimpulkan bahwa tidak ada satu pun gaya kepemimpinan yang tepat bagi setiap manajer di setiap kondisi. Pendekatan situasional-contingency menggambarkan bahwa gaya yang digunakan adalah tergantung pada faktor-faktor seperti situasi, karyawan, tugas, organisasi, dan variabel-variabel lingkungan lainnya.

\section{Gaya Kepemimpinan Delegatif}

Gaya kepemimpinan ini biasa disebut Laissez-faire dimana pemimpin memberikan kebebasan secara mutlak kepada para anggota untuk melakukan tujuan dan cara mereka masing-masing. Pemimpin cenderung membiarkan keputusan dibuat oleh siapa saja dalam kelompok sehingga terkadang membuat semangat kerja tim pada umumnya menjadi rendah. Jenis kepemimpinan ini akan sangat merugikan apabila para anggota belum cukup matang dalam melaksanakan 
tanggung jawabnya dan memiliki motivasi tinggi terhadap pekerjaan (Samsu, 2014). Namun sebaliknya dapat menjadi boomerang bagi perusahaan bila memiliki karyawan yang bertolak belakang dari pernyataan sebelumnya.

\section{PENUTUP}

Pemimpin organisasi yang baik harus mengetahui teori-teori kepemimpinan dan mampu menganalisis bagaimana pola kepemimpinan yang dapat diterapkan pada situasi organisasinya, sehingga dapat mencapai keefektifan organisasi yang dipimpinnya. Terdapat beberapa gaya kepemimpinan, diantaranya: a) gaya kepemimpinan otokratis; b) gaya kepemimpinan demokratis; c) gaya kepemimpinan kharismatik; d) gaya kepemimpinan partisipatif; e) gaya kepemimpinan transformasional; f) gaya kepemimpinan situasional; g) gaya kepemimpinan delegative. Untuk menjadi seorang pemimpin yang efektif, pemimpin tidak hanya terpaku untuk menganut satu gaya kepemimpinan saja tetapi perlu dikombinasikan dengan gaya kepemimpinan yang lain. Setiap gaya kepemimpinan memiliki kekurangan dan kelebihan masing-masing. Hal yang terpenting adalah bahwa seorang pemimpin hendaknya dengan cerdas mengetahui gaya kepemimpinan apa yang harus diterapkan dalam situasi dan kondisi yang saat itu sedang dihadapi dalam organisasi atau kepemimpinannya.

\section{DAFTAR PUSTAKA}

Astuti, A., \& Danial, D. (2019). Kepemimpinan Kepala Madrasah dalam Membangun Budaya Madrasah Yang Kondusif di Madrasah Aliyah Negeri. El-Idare: Jurnal Manajemen Pendidikan Islam, 5(1), 31-45.

Badu, S. Q., \& Djafri, N. (2017). Kepemimpinan dan Perilaku Organisasi. Gorontalo: Ideas Publishing.

Haryono, S. (2015). Intisari Teori Kepemimpinan. Bekasi: Intermedia Personalia Utama.

Hasan, A., \& Mohd, A. (2003). Teori dan Teknik Kepemimpinan: Panduan Aplikasi di Tempat Kerja. Pahang Darul Makmur: PTS Professional.

Lipham, J. M. (1994). The Principaliship: Fundations and Functions. London: Harper and Row.

Naja, H. R. D. (2004). Manajemen Fit dan Proper Test. Yogyakarta: Pustaka Widyatama0.

Pidarta, M. (1998). Manajemen Pendidikan Indonesia. Jakarta: Bumi Aksara.

Purwanto, M. N. (2005). Administrasi dan Supervisi Pendidikan. Jakarta: Rineka Cipta.

Ranoh, A. (2006). Kepemimpinan kharismatik: Tinjauan Teologis-Etis Atas Kepemimpinan. Jakarta: BPK Gunung Mulia. 
Samsu. (2014). Manajemen dan Kepemimpinan Pendidikan. Jambi: PUSAKA.

Steven, A. (1985). Organizational Bahavior, Theori and Practice. Plorida: Academic Press.

Turney. (1992). The School Manager. Australia: Allen and Unwen, 1992.

Wibawa, F. R. D., \& Riyanto, T. (2008). Siap Jadi Pemimpin: Latihan Dasar Kepemimpinan. Yogyakarta: Kanisius. 